Article

\title{
Depictions of Shoeprints in Northwest Portugal
}

\author{
José Moreira ${ }^{1}$ and Ana M. S. Bettencourt ${ }^{2, *(\mathbb{D})}$ \\ 1 FCT_UMINHO/BI/317/2018—Lab2pt/University of Minho, 4710-057 Braga, Portugal; \\ josemaiamoreira@outlook.com \\ 2 Landscape, Heritage and Territory Laboratory-Lab2PT, Department of History, Campus de Gualtar, \\ University of Minho, 4710-057 Braga, Portugal \\ * Correspondence: anabett@uaum.uminho.pt
}

Received: 30 November 2018; Accepted: 20 December 2018; Published: 24 December 2018

\begin{abstract}
From the end of the 3rd millennium and the beginning of the 2nd millennium BCE, new motifs appear in Northwest Portugal. This corresponds to what one of the authors has called Figurative Art. The engravings of human feet-barefoot or with shoes-fall within this new "style". This motif is not well known in Northern Portugal, although it has recently been the subject of a synthesis study on the Atlantic façade of this region. Starting from an inventory work, contextualising the several scales of analysis and the theoretical posture that knowledge is simultaneously cumulative and interpretative, this text reveals the shoeprints existing in Northwest Portugal and the interpretations that have been made about them. Currently there are 81 shoeprints in the region, distributed on 18 outcrops, in 17 different sites. This study has made it possible to create two typological subgroups, namely shoeprints with simple soles and with sole and heel. Within each group it was possible to perceive the existence of places with only one or few shoeprints, versus places with many shoeprints and that there are shoeprints of different dimensions and different orientations. The analysis of this data has made it possible to hypothesise that the engraving of these motifs may have arisen at the end of the Chalcolithic, beginning of the Bronze Age, reaching its peak during the latter period and ending at the beginning of the Iron Age. It is also hypothesised that they represent different age groups and that they may relate to pilgrimages or trips that formed part of rites of passage to adulthood, probably of individuals of higher status within a hierarchised society and which occurred at certain times of year, especially during the summer.
\end{abstract}

Keywords: Northwest Portugal; shoeprints; contexts; chronologies; meanings

\section{Introduction}

Although footprints and shoeprints are relatively frequent motifs in outdoor rock art in the western Iberian Peninsula, few monographic or synthesis studies focus on the centre of Portugal and Galicia.

One of the first known works on representations of feet or sandals/shoes in Portugal refers to north-central Portugal, more specifically to the set in Alagoa, in the municipality of Tondela, in the district of Viseu. During the 1970s, Gomes and Monteiro [1] analysed and described, technically and formally, over one hundred of these motifs, identifying several overlaps. This led them to create a typological chart and to make some chronological and symbolic interpretative considerations on this phenomenon.

In 1994, in the westernmost façade of Spain, Benito del Rey and Grande del Brío [2] published an article about an outcrop with engravings of feet. In 1998, Sevillano San José and Bécares Pérez [3] 
published an article on podomorphs, which they interpreted as pruning hooks ${ }^{1}$ and pentagrams, and dated them to between the second century BCE and the first century AD, relating them to a type of journey of an unknown character. However, in the early 21st century Santos-Estévez and García Quintela published three articles on different morphologies, chronologies and interpretations of footprints in Galicia [4-6]. They tried to relate them to ancient investiture rites from the Iron Age, with parallel sources from the Late Middle Ages to the 19th century, in Ireland, Scotland, Wales, France, Austria, Basque Country (Spain), among others, which relate to previous periods. Nevertheless, the foundations for this interpretation have been strongly criticised by M. Llinares García [7].

In 2010, Gomes [8] re-addressed this phenomenon in the context of the rock art of the Tagus Valley, in the centre of Portugal, and published a survey of numerous footprints of different typologies. Using several methodologies, he tried to determine the possible ages and heights of the individuals who, hypothetically, served as models for the engravings. He placed these motifs between the Late Bronze Age and the Early Iron Age and interpreted them as possible representations of the use of shoes or sandals by the aristocracy and priests, which is attested in some places in the Middle East [8] (pp. 242-243). In the art of the Tagus valley, this author identified footprints that correspond "clearly to the footprints of imaginary beings" ${ }^{\prime 2}$. They are of very small dimensions, filled with perforations, some with more than five toes [8] (p. 246). Three of extraordinary dimensions were also identified, which might be explained by the possible attribution of greater importance to certain mythical and sacred personages or might be related to individuals of abnormally large stature [8] (p. 247).

Additionally, in 2010, Ribeiro et al. [9] analysed these motifs, engraved in the watersheds of the Ceira and Alva Rivers, both tributaries of the Mondego River Basin, in central Portugal. In this study, they create a new typological table, trying to fit the footprints in contextual terms and argue that the existence of a great concentration of engraved slabs, in places that have always assumed the role of natural routes of passage, such as interfluves along the lines of ridges, makes it possible to hypothesise that footprints limit "in some cases not only geological but also (...) cultural realities"3 [9] (p. 204). As in most cases the footprints and their related supports are oriented towards Southeast, they admit that the horizon observed by worshipers might have been characterised by sunset and/or full moon, around the summer solstice [9] (p. 204). As to the size of the footprints, the presence of some smaller ones seems to indicate the representation of the feet of children. This apparent concern to represent the younger members of the group and/or family and to mark a certain place "could be the proof of the sacredness of the spaces themselves, (...) also representing renewal and therefore linked to fertility"4 [9] (p. 208).

Although, in 2012, Abreu [10] produces an inventory of footprints and shoeprints on rock art in Portugal, based on an extensive research and bibliographic synthesis, he does not provide major interpretive considerations on the phenomenon. The same can be said of Garcês who, in 2016 [11], only mentions some podomorphs for the Tagus valley, without great chronological precision.

Finally, in 2018, the first author of this paper synthesises the footprints and shoeprints of the North-west of Portugal [12] in an academic work, having, for the first time, valorised this typological difference in the analysis carried out. From there, he puts forward hypotheses about ages, meanings and chronologies for each of the engraved places with each type of motif.

This article is based on the latter work and provides some data and considerations about the shoeprints of the westernmost façade of Northern Portugal.

Northwest Portugal, which borders to the north with Galicia, Spain, is a mountainous region, with reliefs in amphitheatre that rise from the coast to the interior. It is crossed by several rivers that

\footnotetext{
What the authors consider to be pruning hooks seem to be curved handles that carry axes, in a much older imagery.

"claramente a pegadas de seres imaginários"

"nalguns casos não só realidades geológicas, mas também ( ... ) culturais"

"poderá ser a prova da sacralização dos próprios espaços, ( . . ) representando igualmente a renovação e por isso ligado à fertilidade"
} 
run, sensibly, from northeast to southwest and flow into the Atlantic Ocean. It is a region that is rich in tin and gold resources (Figure 1).

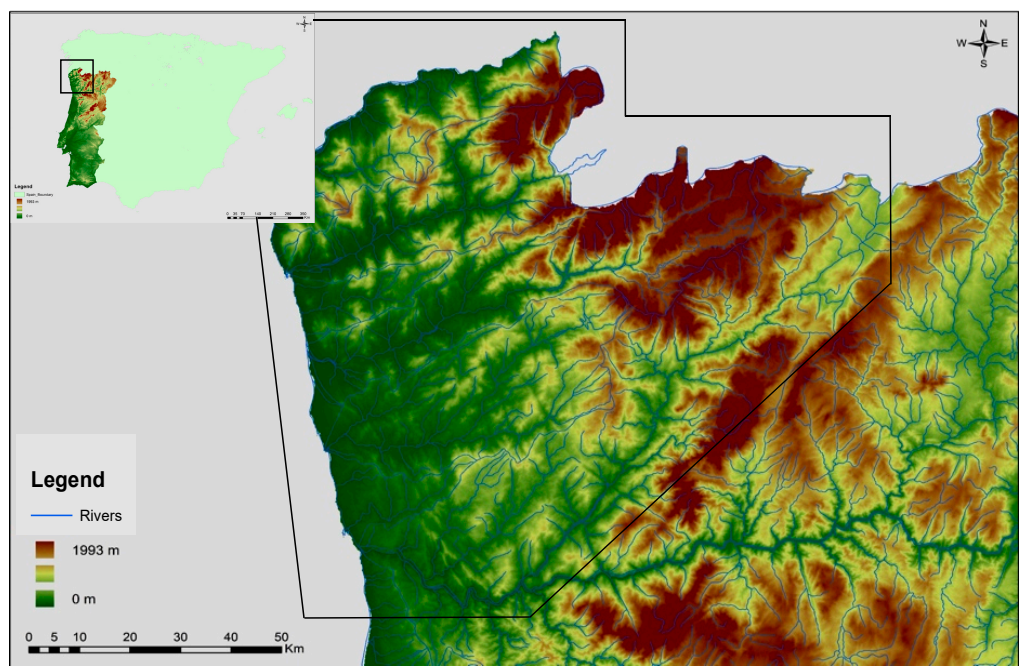

Figure 1. Identification of the study area in Portugal and in the context of the Iberian Peninsula.

\section{Methodology}

In theoretical terms this work started from the premise that knowledge is both cumulative and interpretive and that the material findings correspond to expressions of the social and symbolic world of the communities that elaborated and attended them.

In practical terms, the work was organised in three stages: initial desk research, fieldwork and advanced desk research. In the first stage, a review of the existing knowledge and questions about footprints and shoeprints on the westernmost façade of the Iberian Peninsula was carried out; consultation of bibliography, in order to consolidate the theoretical body of work, and bibliography and cartography, for physical and environmental contextualisation of the area under study. Fieldwork implied archaeological prospecting, planned from a preliminary inventory and conducted on the basis of the bibliographical research. The objective was to relocate sites that had already been identified, while making it possible to discover other unpublished sites. Each archaeological site was inventoried, which included its administrative location and its physical and archaeological context, as well as the description of the outcrop and the motifs found therein. Daytime, generic, and detailed photographs and nocturnal photographs were also taken when provided. In two cases (Fraga das Passadas and Penedo de S. Gonçalo), permission was requested from the Direção Regional de Cultura Norte (Northern Regional Directorate for Culture), to carry out cleaning and more detailed study of the recorded motifs, through photogrammetry. For this purpose, the combination of the Agisoft Photoscan ${ }^{5}$ and Meshlab ${ }^{6}$ programmes were used. Legends associated to the inventoried sites were also collected.

The advanced desk research comprised interrelation of the totality of the obtained data and spatial analysis. This made it possible to discuss the data and draw up interpretations thereof.

\section{The Data}

Of the 219 footprints identified in Northwest Portugal [12], it was possible to identify 81 shoeprints, which are distributed on 18 outcrops, located in 17 archaeological sites. These are located mainly in the

\footnotetext{
Agisoft LLC 11 Degtyarniy per., St. Petersburg, Russia, 191144.

Istituto di Scienza e Tecnologie dell'Informazione “A. Faedo", Pisa, Italy, 56124; Consiglio Nazionale delle Ricerche, Roma, Italy, 00185 .
} 
innermost areas of the northwest, with only one exception, the shoeprint of Salgueiro 1 (no. 14), in Carreço, Viana do Castelo (Figure 2) ${ }^{7}$.

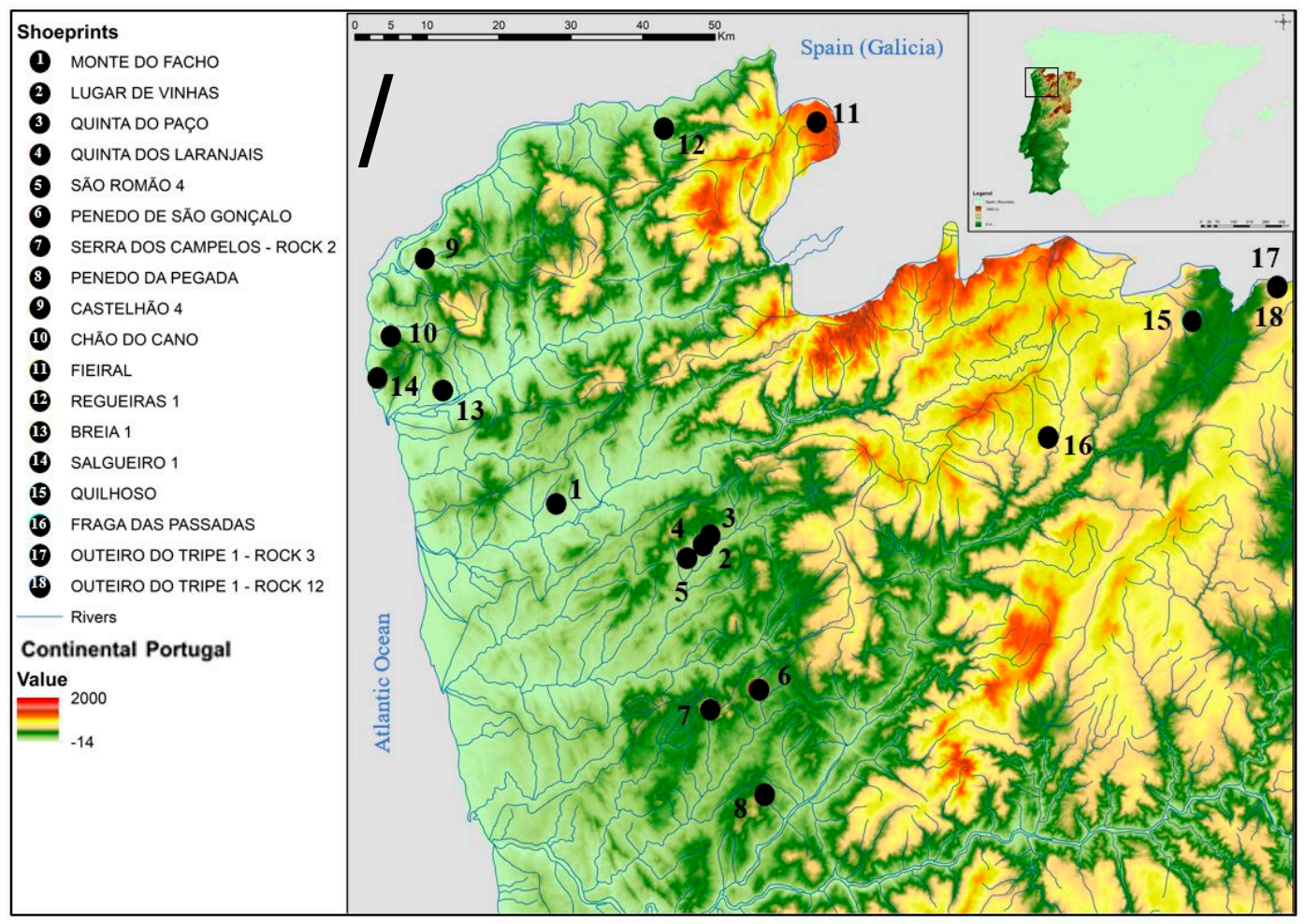

Figure 2. Geographic distribution of Northwest shoeprints.

They are distributed mainly in low and medium altitude areas (up to $700 \mathrm{~m}$ ), which corresponds to $78 \%$ of the cases. Above $700 \mathrm{~m}$ there are only four cases identified, i.e., $22 \%$. The majority are located on slopes ( $78 \%$, corresponding to 13 cases), with rare exceptions in the bottom of the valleys $(17 \%$, or three cases) and in the summit of the mountains (11\%, which corresponds to two cases) (Table 1 , Figure 3). In any of the situations mentioned, they occur in natural areas of passage and are easily accessible from the valleys.

Table 1. Topographic location of outcrops with shoeprints.

\begin{tabular}{ccc}
\hline $\mathbf{N}^{\mathbf{0}}$ & Outcrops & Topographic Location \\
\hline 1 & Monte do Facho & Slope of the hill \\
2 & Lugar de Vinhas & Bottom of the valley \\
3 & Quinta do Paço & Slope of the hill \\
4 & Quinta dos Laranjais & Slope of the hill \\
5 & São Romão 4 & Top of the hill \\
6 & Penedo de S. Gonçalo & Bottom of the valley \\
7 & Serra dos Campelos-Rock 2 & Slope of the hill \\
8 & Penedo da Pegada & Slope of the hill \\
9 & Castelhão 4 & Slope of the hill \\
10 & Chão do Cano & Slope of the hill \\
11 & Fieiral & Top of the hill \\
12 & Regueiras 1 & Bottom of the valley \\
13 & Breia 1 & Slope of the hill \\
14 & Salgueiro 1 & Slope of the hill \\
15 & Quilhoso & Slope of the hill \\
16 & Fraga das Passadas & Slope of the hill \\
17 & Outeiro do Tripe 1-Rock 3 & Slope of the hill \\
18 & Outeiro do Tripe 1-Rock 12 & Slope of the hill \\
\hline
\end{tabular}

7 Outcrops were considered close to the coastline, when located less than $2.5 \mathrm{~km}$ from the ocean, in a straight line. 


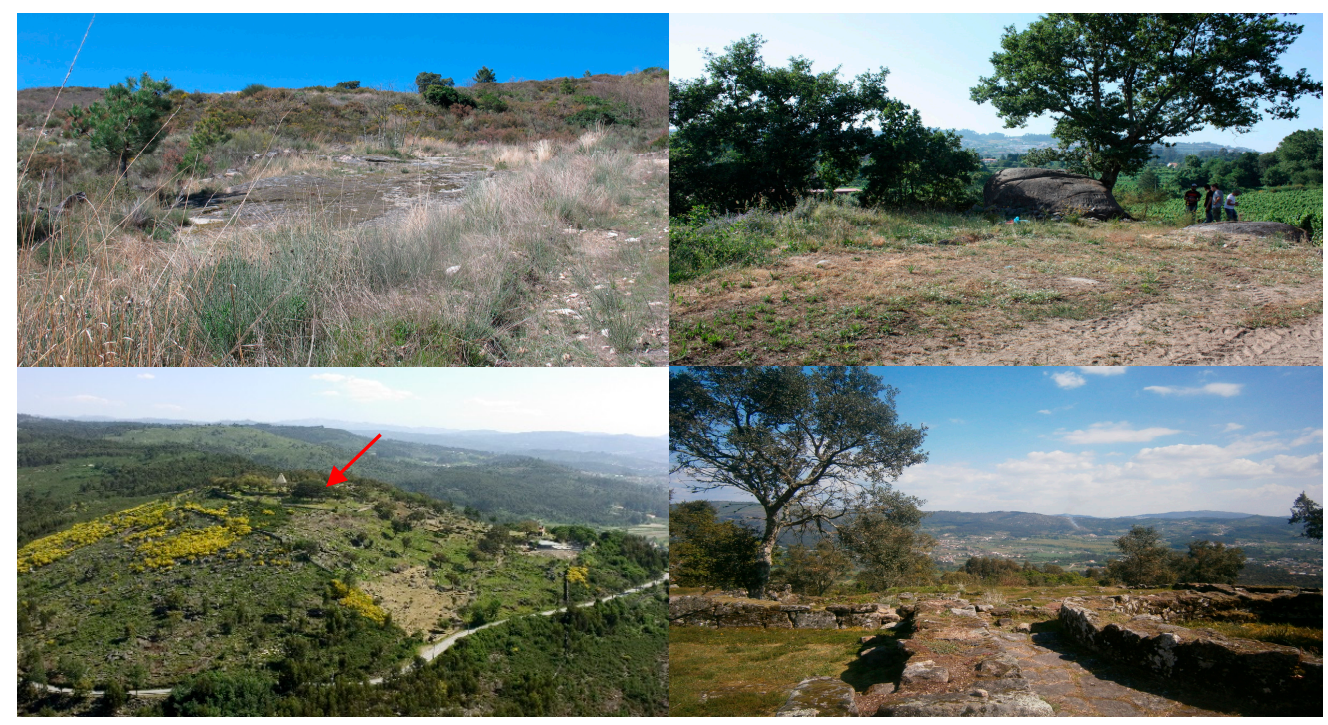

Figure 3. From left to right and from top to bottom-Fraga das Passadas (no. 16), Chaves, top of the slope; Penedo de S. Gonçalo (no. 6), Felgueiras, bottom of the valley; S. Romão 4 (no. 5), Guimarães, top of the hill (view 1 and 2).

In relation to geology, all recorded outcrops are granitic, although of different types and colourations.

As for the topography of the engraved outcrops, the shoeprints are mainly found on outcrops that are not very prominent in the soil, and therefore are hardly perceptible from a distance. This is the case of $58.02 \%$ of the samples (Figure 4). However, they are also inscribed on high rocks in relation to the soil and of great visual impact, in $37.03 \%$ of the cases (Figure 5). There are four outcrops in which it was not possible to determine their characteristics for different reasons.

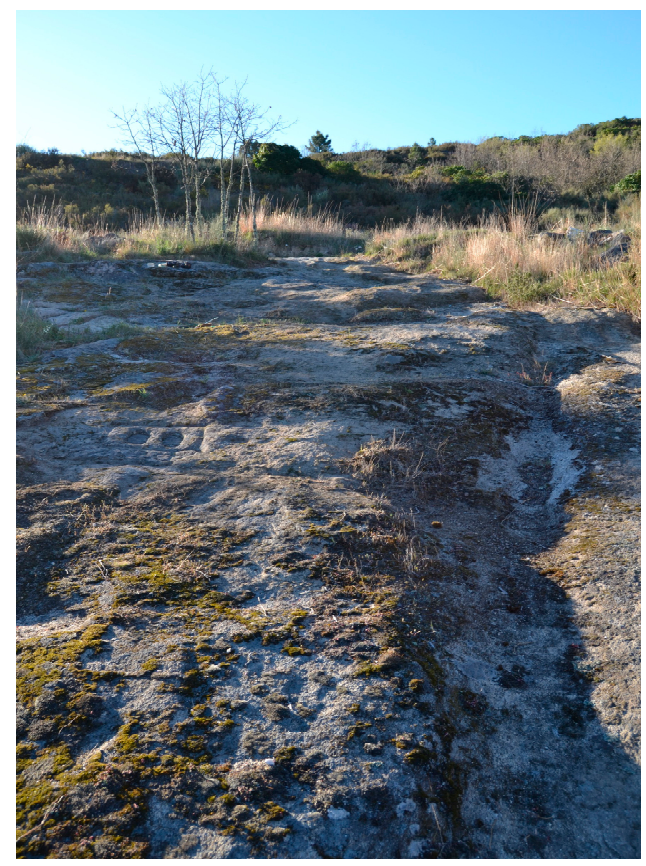

Figure 4. Fraga das Passadas (no. 16), Chaves-Shallow slab to the ground and little demarcated in the landscape [12] (p. 269). 


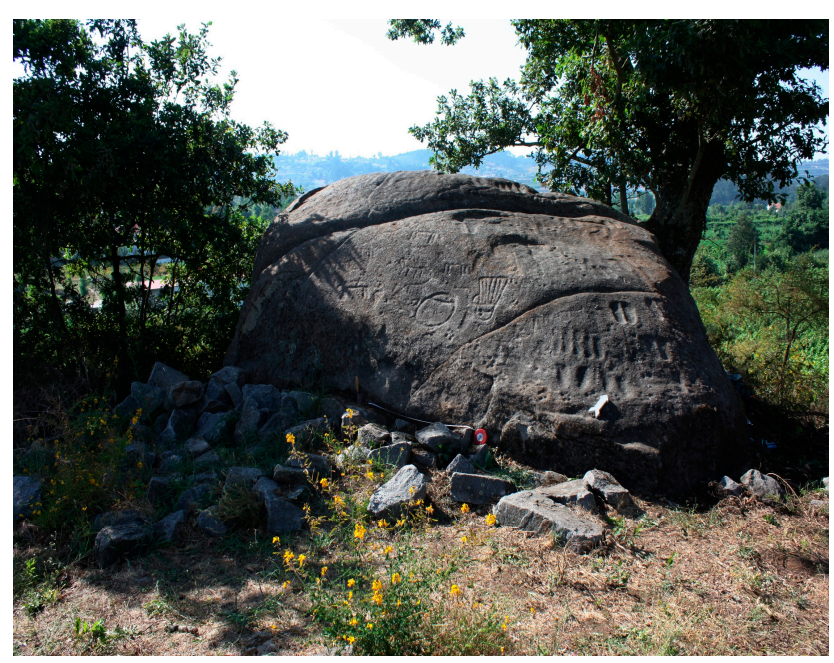

Figure 5. Penedo de S. Gonçalo (no. 6), Felgueiras—Raised and well-perceived outcrop [12] (p. 269).

The visibility characteristics of the engraved outcrops were determined "based on personal observations, cartographic analysis and bibliographic sources. It was also assumed that the vegetation cover around the engraved outcrops would be more open than at present, which might not occur ${ }^{\prime \prime} 8$ [12] (p. 275). Taking into account these premises, from the outcrops recorded with shoeprints there would be a broad visibility from the surrounding area, at least for some quadrants, in $83.33 \%$ of the cases, corresponding to 15 cases. In the remaining three, there were no conditions to determine this study variable.

Although there are typological tables, both for the footprints of the Ceira and Alva rivers, in the Centre of Portugal [9], as well as those of Alagoa, in the centre-north [1,8], it was chosen to make a proper typology to the case studies, given the specificities of Northwest Portugal [12]. This work considered shoeprints with a rounded or oval upper end, of width superior or almost equal to the inferior extremity. In this definition we considered the archaeological data or representations of prehistoric soles known in Iberia, in a similar way. Such is the case of the Neolithic soles, of vegetal fibres, of the cave of Murciélagos de Albuñol, in Granada [13]; of the pair of limestone sandals from one of the Alapraia hypogeums in Cascais $[8,14]$ and those represented in the Alentejo stele of Ervidel I in Aljustrel [1,15].

It was based on these characteristics that, in Northwest Portugal, 81 shoeprints were identified, although differences were noted among them that justified the creation of subcategories. Thus, shoeprints were subdivided into shoeprints with representations of simple soles (49\%) and shoeprints with sole and heel representation (51\%) (Table 2).

Table 2. Types of shoeprints.

\begin{tabular}{cc}
\hline Shoeprints & No. \\
\hline With simple sole & 40 \\
With sole and heel & 41 \\
TOTAL & $\mathbf{8 1}$ \\
\hline
\end{tabular}

In each one of categories, specificities were also identified, which in the case of shoeprints with a simple sole, some (rare) visible marks were observed that were interpreted as representations of straps. In contrast, one was identified in which the rim of the sole and heel was defined by perforation (Table 3).

8 "com base em observações pessoais, na análise cartográfica e nas fontes bibliográficas. Parte-se, igualmente, do princípio de que o coberto vegetal, em redor dos afloramentos gravados, seria mais aberto do que atualmente, o que poderia não ocorrer" 
Table 3. Typology of shoeprints and subdivisions.

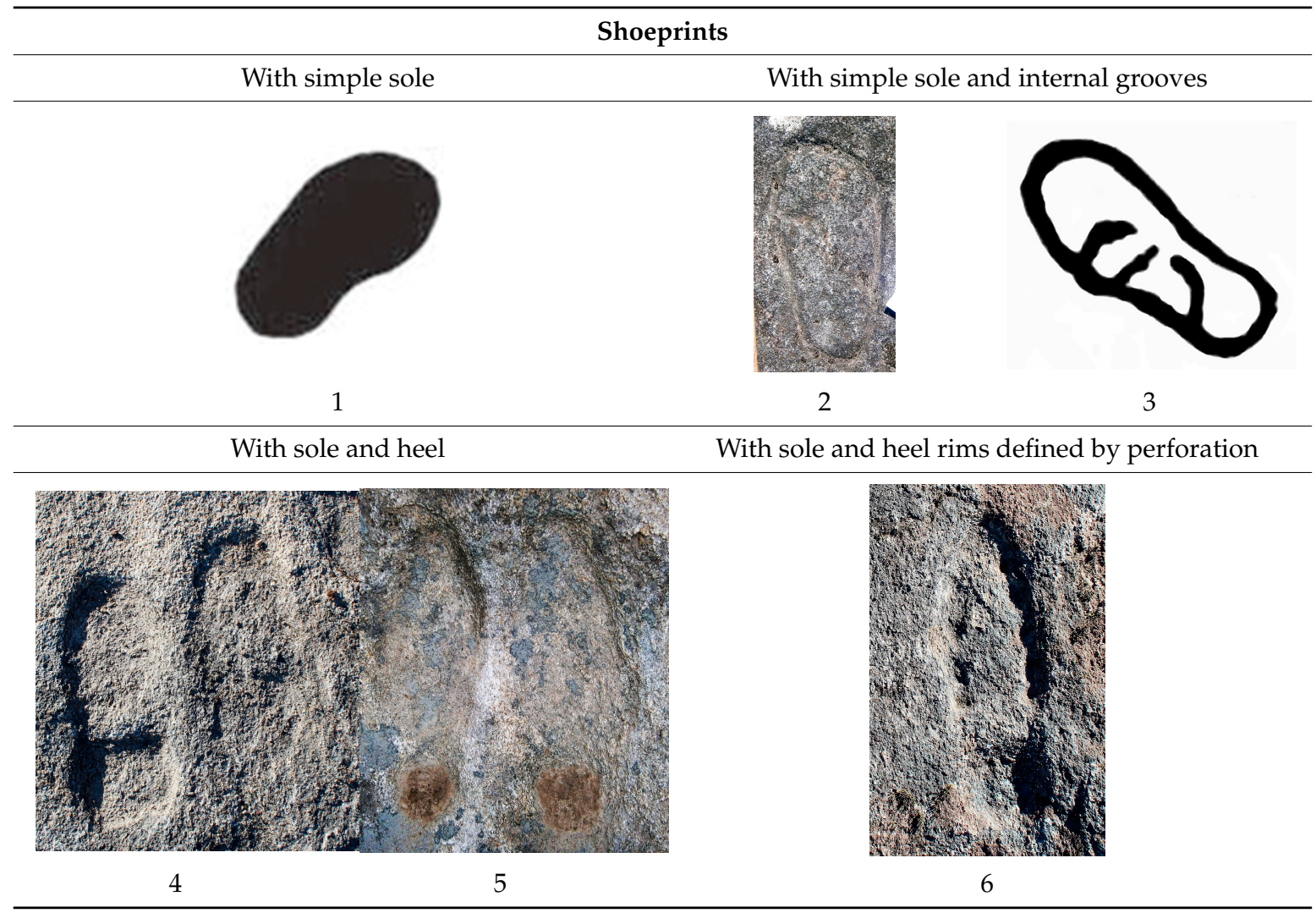

1—Monte do Facho (no. 1), Barcelos; 2—São Romão 4 (no. 5), Guimarães; 3-Outeiro do Tripe 1-Rock 12 (no. 18); 4 to 6-Fraga das Passadas (no. 16), Chaves.

Although the shoe is always bigger than the foot, the methodology used to establish age groups was based on the size of the feet, taking into account the specialised literature on human feet [16-22]. Three dimensional intervals were created. The first dimensional range comprises engravings less than $23 \mathrm{~cm}$ in length; the second comprises engravings between $23 \mathrm{~cm}$ and $32 \mathrm{~cm}$ in length, and the third those more than $32 \mathrm{~cm}$.

In view of these intervals, it has been found that the dimensions of the shoeprints are very varied, although they are inserted essentially in the first interval, i.e., up to $22 \mathrm{~cm}$, which comprise feet smaller than this dimension. This occurs in 44 cases, which corresponds to $54 \%$ of the total sample. Note that among these shoeprints, there are 14 measuring less than $17 \mathrm{~cm}$. The remainder were distributed in the second interval, in 29 cases, i.e., $36 \%$ of the sample, and in the third interval, with six cases, which corresponds to only $7 \%$ of the total. In this last interval there are 4 cases measuring more than $40 \mathrm{~cm}$ in length. There are also two shoeprints of indeterminate size (Table 4, Figures 6 and 7).

Table 4. Number of shoeprints belonging to each typology, distributed across the different dimensional ranges.

\begin{tabular}{ccccccc}
\hline Typology of Shoeprints & $<\mathbf{1 7} \mathbf{~ c m}$ & $\mathbf{1 7} \mathbf{a} \mathbf{2 2} \mathbf{~ c m}$ & $\mathbf{2 3} \mathbf{~ a ~} \mathbf{3 2} \mathbf{~ c m}$ & $\mathbf{3 3} \mathbf{~ a ~} \mathbf{3 9} \mathbf{~ c m}$ & $>$ /= $\mathbf{4 0} \mathbf{~ c m}$ & Ind. \\
\hline With simple sole & 8 & 20 & 10 & 0 & 0 & 2 \\
With sole and heel & 6 & 10 & 19 & 2 & 4 & 0 \\
TOTAL & $\mathbf{1 4}$ & $\mathbf{3 0}$ & $\mathbf{2 9}$ & $\mathbf{2}$ & $\mathbf{4}$ & $\mathbf{2}$ \\
\hline
\end{tabular}




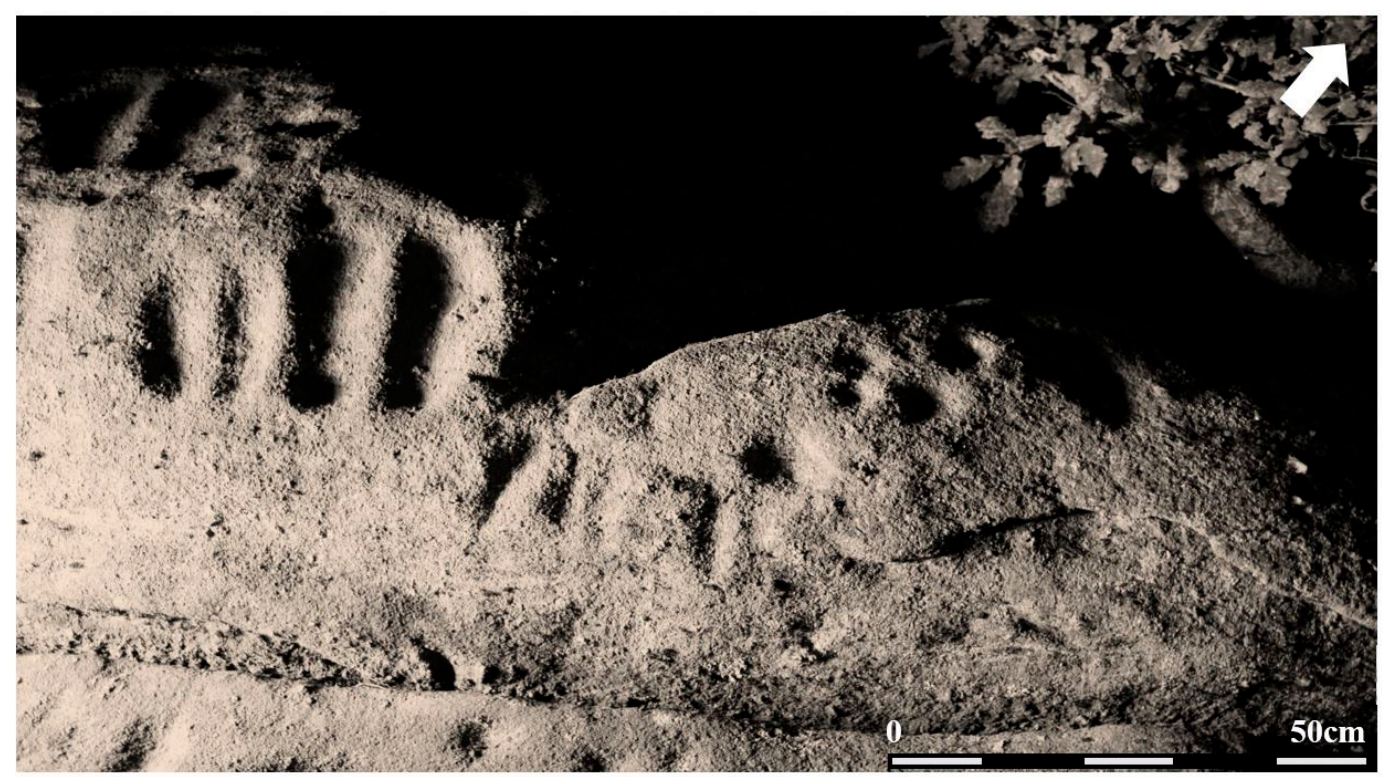

Figure 6. Left: shoeprints with sole and heel, less than $23 \mathrm{~cm}$; on the right: shoeprints between $23 \mathrm{~cm}$ and $32 \mathrm{~cm}$-Penedo de S. Gonçalo (no. 6), Felgueiras.

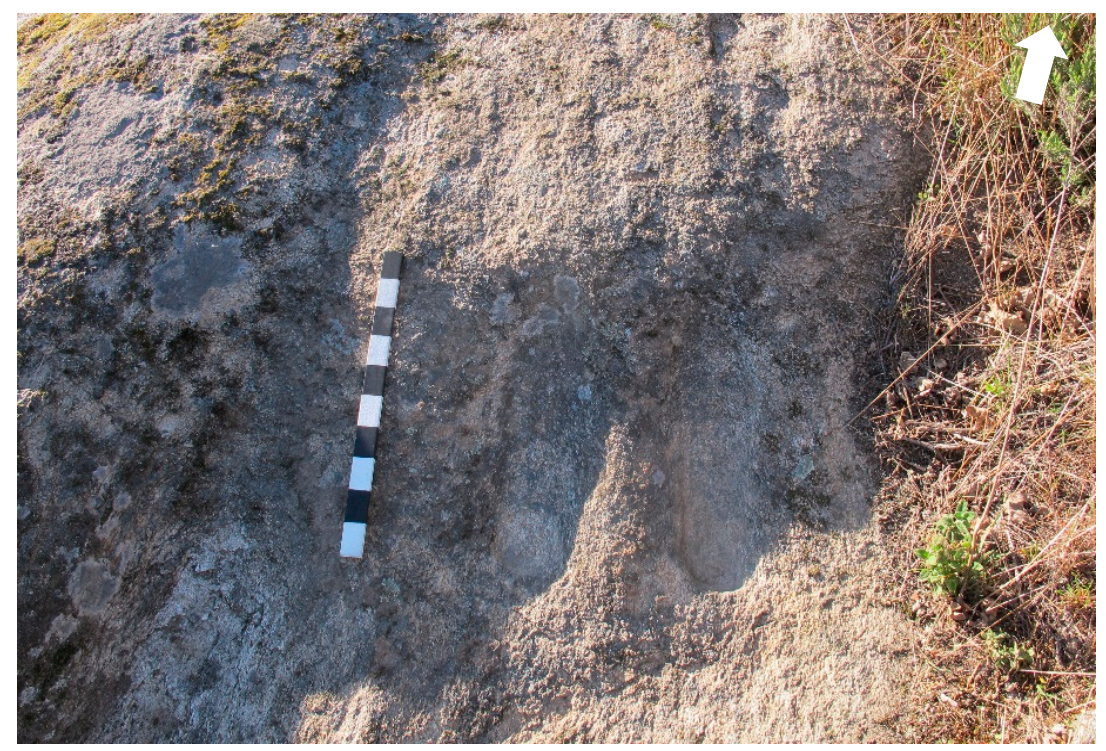

Figure 7. Shoeprints with sole and heel, with more than $32 \mathrm{~cm}$-Fraga das Passadas (no. 16), Chaves.

They are different in relation to typologies. Shoeprints with simple soles correspond mostly to the group of smaller feet, wherein those with a heel have their greatest representativeness in the range from 23 to $32 \mathrm{~cm}$. They are also the only ones greater than $32 \mathrm{~cm}$.

It was also verified that both right-foot and left-foot shoes were shown in more or less similar numbers, either in pairs or individually, wherein the majority of pairs are shoeprints with simple soles, whereas the opposite is found for shoeprints with a sole and heel (Table 5).

Table 5. Shoeprints of right feet and left feet; pairs and individually.

\begin{tabular}{ccccccc}
\hline Typology of Shoeprints & Right Feet & Left Feet & Ind. & Pairs & Individuals & Ind. \\
\hline With simple sole & 19 & 20 & 1 & 15 & 10 & 0 \\
With sole and heel & 14 & 12 & 15 & 11 & 17 & 2 \\
TOTAL & $\mathbf{3 3}$ & $\mathbf{3 2}$ & $\mathbf{1 6}$ & $\mathbf{2 6}$ & $\mathbf{2 7}$ & $\mathbf{2}$ \\
\hline
\end{tabular}


As for the 40 shoeprints with simple soles, we identified 19 right feet, 20 left feet, and one undetermined foot. These are organised into 15 pairs and 10 individual pairs (Figures 8 and 9).

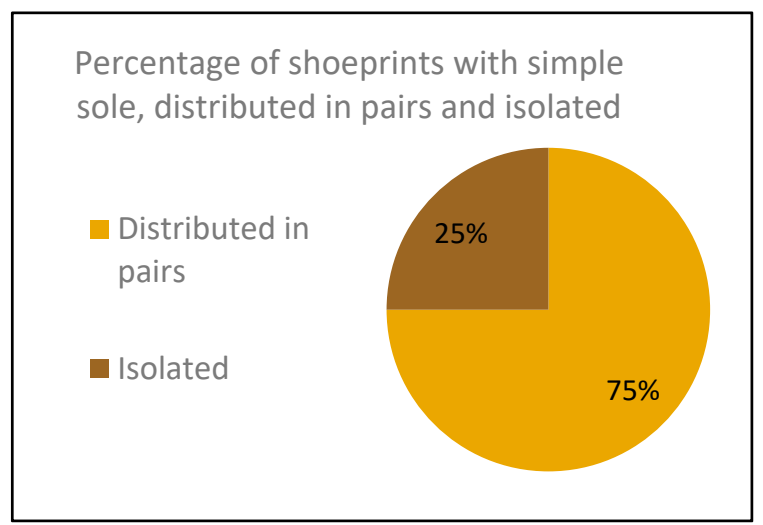

Figure 8. Percentage of simple, right and left, shoeprints.

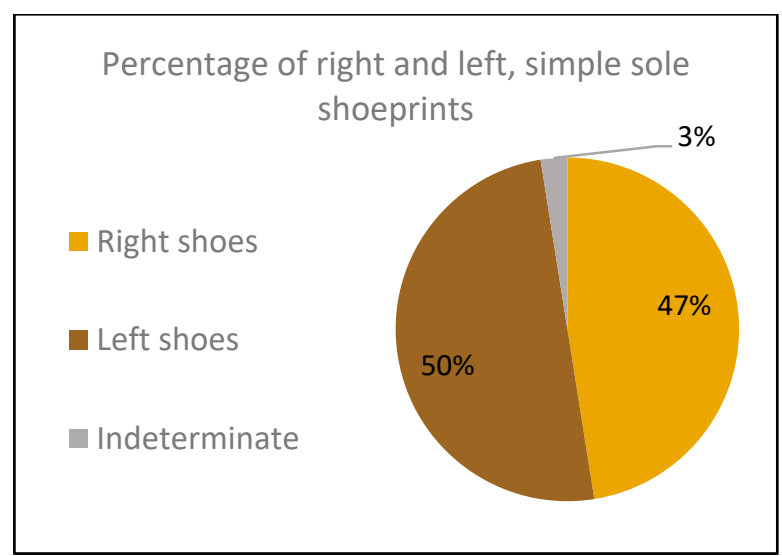

Figure 9. Percentage of simple shoeprints, in pairs and isolated.

As for the shoeprints with heel, of the 41 identified, 14 represent right feet and 12 represent left feet. The remaining 15 are not known. Some of these footprints form pairs, 11 in total, others appear isolated, as found on 17 occasions. It was not possible to obtain this type of information for the remaining two footprints (Figures 10 and 11).

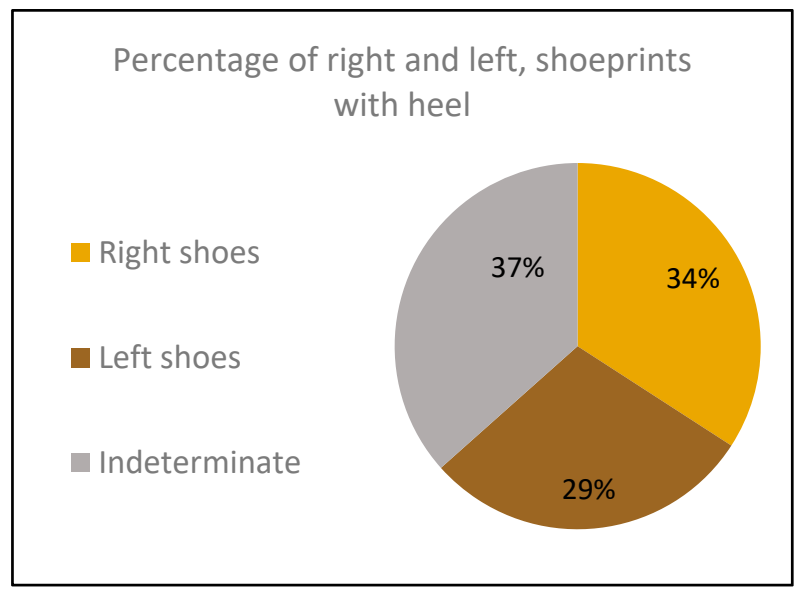

Figure 10. Percentage of, right and left, shoeprints with heel. 


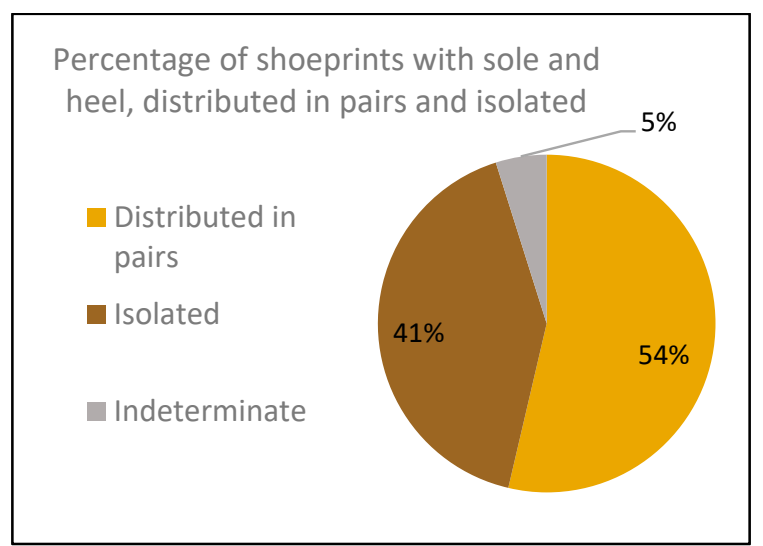

Figure 11. Percentage of shoeprints with heel, in pairs and isolated.

Regarding the orientations of the shoeprints, these occur in several directions, but there is a clear tendency for them to be oriented towards the northwest (Table 6).

Table 6. Orientations for the different types of shoeprints.

\begin{tabular}{ccc}
\hline Orientations & With Simple Sole & With Sole and Heel \\
\hline Northwest & $\mathbf{2 4}$ & $\mathbf{3 1}$ \\
Southeast & 4 & 4 \\
North & 3 & 0 \\
West & 3 & 3 \\
Northeast & 0 & 2 \\
Southwest & 1 & 1 \\
South & 1 & 0 \\
Indeterminate & 4 & 0 \\
TOTAL & $\mathbf{4 0}$ & $\mathbf{4 1}$ \\
\hline
\end{tabular}

Shoeprints with simple soles, totalling 40, are mostly oriented to the northwest, although some are oriented to the southeast, north, west, southwest, and south (Figure 12). As for the shoeprints with sole and heel, 41 in total, these are also mainly oriented to the northwest. There are still some in the southeast, west, northeast, and southwest directions, with none oriented either north or south (Figure 13).

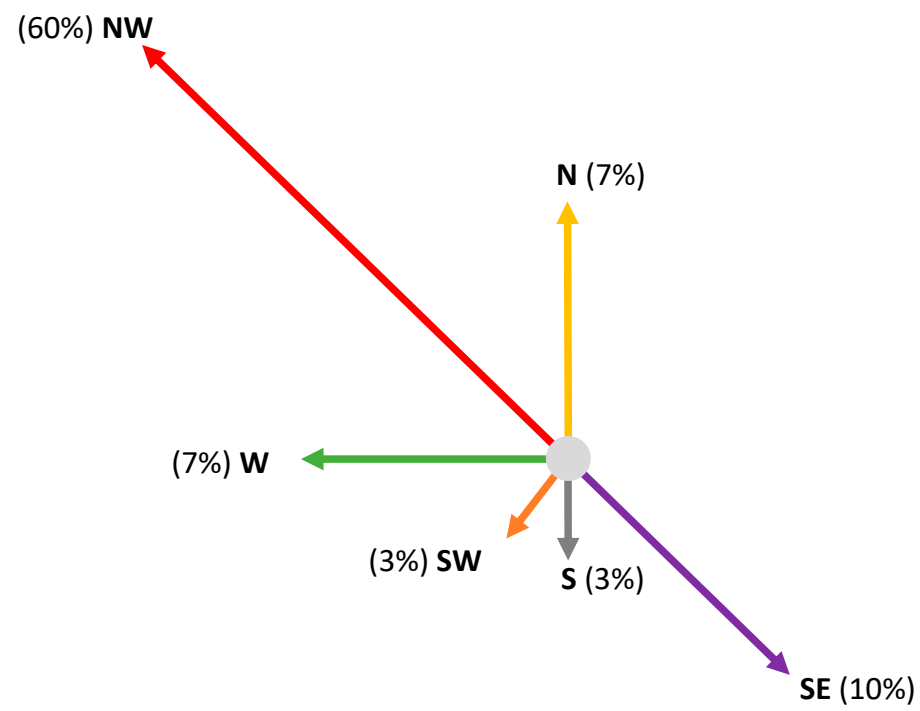

Figure 12. Orientations of the shoeprints with simple sole (indeterminate: 10\%). 


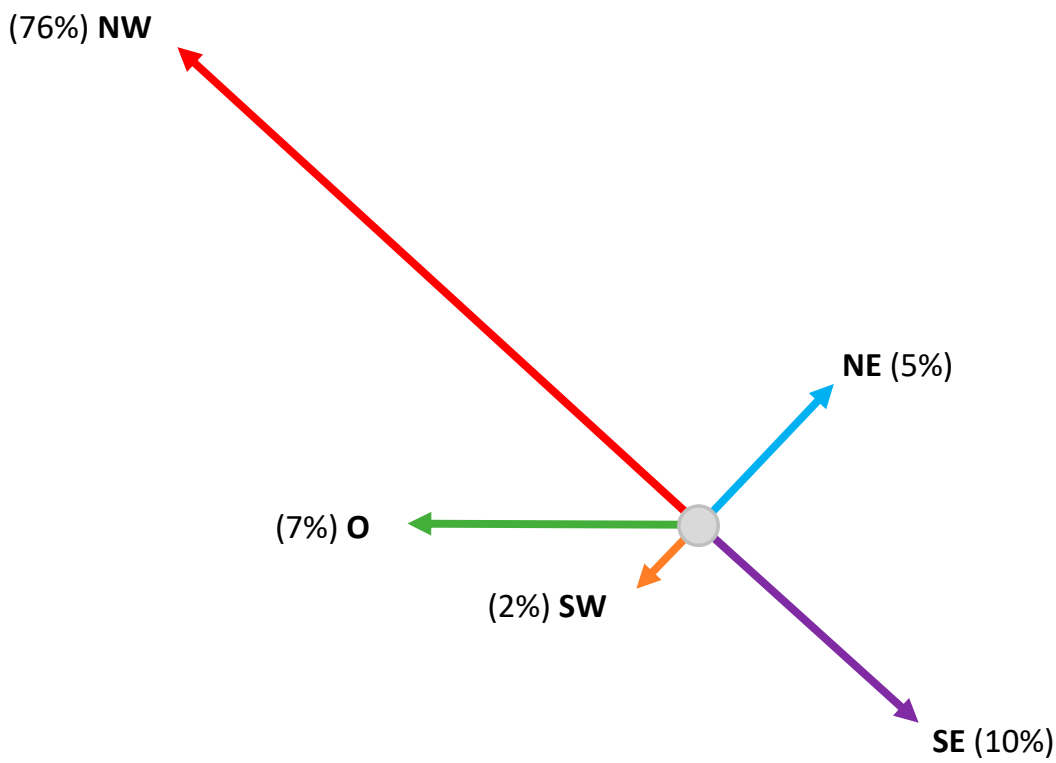

Figure 13. Orientations of the shoeprints with sole and heel.

The technical aspects of the shoeprints were also taken into account in the study. It was verified that most of them were produced in low relief (74 cases), which corresponds to $91 \%$ of the sample. In turn, only five cases $(6 \%)$ were drawn in a contour line, always through percussion, followed by abrasion, resulting in wide and U-shaped grooves. It is not known how two cases with soles were produced (Table 7).

Table 7. Technical aspects of shoeprints, related to their different typologies.

\begin{tabular}{cccc}
\hline Typology of Shoeprints & Low Relief & Contour Line & Ind. \\
\hline With simple sole & 35 & 3 & 2 \\
With sole and heel & 39 & 2 & 0 \\
TOTAL & $\mathbf{7 4}$ & $\mathbf{5}$ & $\mathbf{2}$ \\
\hline
\end{tabular}

\section{Discussion of Data and Interpretations}

The chronological-cultural question will be the first to be discussed. Due to the fact that there are no excavations carried out around these engraved sites, that could contribute with further data for their chronological and cultural insertion, horizontal stratigraphy was used, analysing the way the shoeprints were inserted in outcrops recorded with Classical Atlantic Art, and Early Schematic Art, considered to be older. Parallels with other similar, but contextualised, manifestations on the western façade of the Iberian Peninsula were also taken into account.

In the universe of 18 outcrops, shoeprints occur, as the only motif or with motifs that do not fall into any of the two aforementioned artistic styles, in eight outcrops, corresponding to $44 \%$ of the sample. In five cases (28\%) they associate with Classical Atlantic Art; in four (22\%) with Early and Late Schematic Art and in one case (6\%) with the two aforementioned styles.

An attentive observation of each case made it possible to perceive that, when related to Classical Atlantic Art, shoeprints invariably appear in a peripheral position to the compositions that characterise them, as if they were additions. When associated with Early Schematic Art, the same thing happens. In this way, and since these styles have been dated from the Neolithic period until the Chalcolithic, i.e., since the 5th to 3rd millennia BCE [23-33], the shoeprints should be later, representing, in this case, phenomena of reuse of previous significant spaces. When related to Late Schematic Art, dated by Bettencourt [23] between the Early Bronze Age and the Iron Age, i.e., the end of 3rd to the 1st millennia $\mathrm{BCE}$, both are engraved on the periphery of these compositions and blended with them, so that they 
may be later or of the same generic period. In relation to the overlaps, there is only one shoeprint partially superimposed by a Latin cross, of historical origin.

Thus, the shoeprints of Northwest Portugal probably arose at the end of the Chalcolithic, beginning of the Bronze Age, i.e., at the transition from the 3rd to the 2nd millennia BCE, having remained at least until the Late Bronze Age or Early Iron Age.

This proposal coincides with the chronology given to objects of this form or to other representations of existing shoeprints for the Centre and South of Portugal, as is the case of the pair of sandals, in limestone, engraved in one of the hypogeums of Alapraia [8,14] (p. 238), dated from the Late Chalcolithic/Early Bronze; of the pair of sandals depicted in the Alentejo stele of the Ervidel I (Aljustrel), dating to the Middle Bronze [1,15] and the sandals associated with arms of the SW stele of Gomes Aires, inserted in the Late Bronze [34-36].

The engraving of shoeprints began to disappear at the beginning of the Iron Age, if we consider that steles with these motifs were reused in the necropolis of Pardieiro II and III, and these were considered prior to the sidereal epigraphy by Jiménez Ávila [37].

As to the origin of the shoeprints in Northern Portugal, considering that they are found in greater abundance in the Centre and the interior of Northern Portugal (Figures 14 and 15), the hypothesis is that in the most western façade they correspond to a manifestation which would have spread from south to north and east to west, by land and river, perhaps related to the movement of people, goods, and ideologies, within the framework of supra-regional exchange networks, having been assimilated locally at different rates.

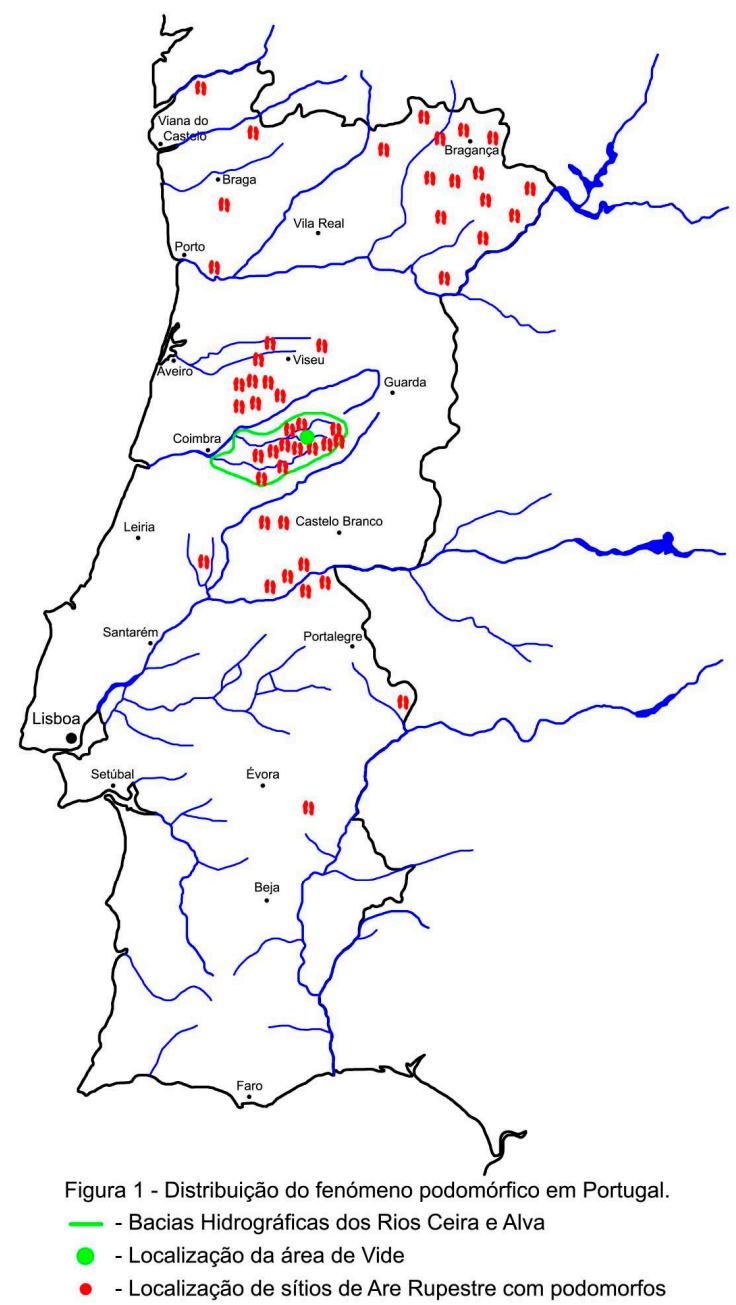

Figure 14. Map of distribution of podomorphs [9] (p. 202) —adapted. 


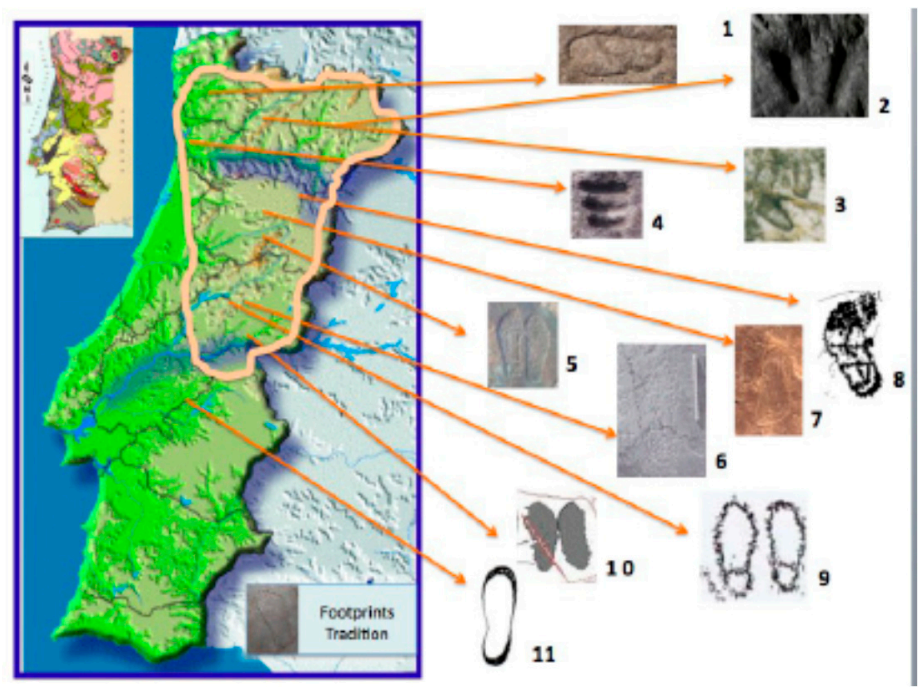

Figure 15. Map of distribution of the podomorphs, [10] (p. 413)_adapted. Distribution map of isolated and in pairs podomorphs: 1. Braga, Guimarães, Castro Sabroso. 2. Bragança, Macedo de Cavaleiros, Santa Combinha, Fraga da Pegada. 3. Vila Real, Valpaços, Fraga das Passadas. 4. Porto, Penafiel, Luzim, "Pegadinhas de S. Gonçalo"—Lomar. 5. Coimbra, Seia, Vide, Fontes de Cide. 6. Coimbra, Pampilhosa da Serra, Vale do Gato, Malhada do Rei. 7. Viseu, Tondela, Alagoa. 8. Douro, Guarda, Vila Nova de Foz Côa, Vale da Casa. 9. Coimbra, Pampilhosa da Serra, Vale do Gato, Malhada do Rei. 10. Castelo Branco, Oleiros, Sesmarias. 11. Évora, Reguengos de Monsaraz.

Another interesting aspect that deserves discussion is the diversity of the number of shoeprints existing in different outcrops, a characteristic also verified for outcrops where footprints have been recorded, either by Bettencourt [23] or by Moreira [12]. From the analysis of Table 8 it can be verified that outcrops with only one shoeprint predominate, equivalent to $67 \%$ of the sample, followed by those with only one pair or two shoeprints. There is a smaller number of sites with numerous podomorphs (Table 8): Fraga das Passadas, in Chaves, where at least 37 shoeprints were counted, and Penedo de S. Gonçalo, in Felgueiras, with 24 shoeprints. In the first case only, shoeprints with sole and heel are shown, although there are also footprints. In the second case, all shoeprints represent simple soles, but also coexist with footprints [12]. They are both large outcrops, although the engraved surface of the two is varied, fairly horizontal in one case and steeply inclined in the other one. One is located at the bottom of the valley and another at half-slope. Both provide major visibility over the surrounding landscape. However, Table 8 reveals that this reality is geographically more significant in the case of shoeprints with simple soles than in those with sole and heel. Against this background it is hypothesised that in both cases there would have been places with differentiated but interrelated meanings. In other words, very important places frequented by a large number of people, perhaps in a repeated manner over time-with many shoeprints—and places of less collective importance, frequented by few people or only visited by one or two-with one or two shoeprints.

Table 8. Number of shoeprints per outcrop.

\begin{tabular}{cc}
\hline Shoeprints per Outcrop & No. and \% of Outcrops \\
\hline One shoeprint & $12(67 \%)$ \\
One pair or two shoeprints & $4(22 \%)$ \\
Between three and 10 shoeprints & 0 \\
With more than 10 shoeprints & $2(11 \%)$ \\
TOTAL & 18 \\
\hline
\end{tabular}

Through a comparative analysis between sites with a single shoeprint and between them and those with multiple shoeprints, an attempt was made to establish the existence of regularities and or 
specificities that could reveal which characteristics of the physical world would have been important in the differentiation of such places. Taking into account Table 9, the results were inconclusive. In all of them there is ample visibility for the surrounding space and physical contexts and types of diversified outcrops, so these characteristics were not taken into account for the differentiation of these sites.

Table 9. Number of shoeprints per outcrops and their features.

\begin{tabular}{|c|c|c|c|c|}
\hline No. of Shoeprints & Typology & \multicolumn{2}{|c|}{ Physical Contexts } & \multirow{2}{*}{$\begin{array}{c}\text { Outcrops Particularities } \\
(?)\end{array}$} \\
\hline \multirow{12}{*}{1 shoeprint } & With simple sole & Middle of the slope & Wide visibility & \\
\hline & With simple sole & Valley bottom & - & $\begin{array}{l}\text { Little detached from the ground, } \\
\text { not very impressive }\end{array}$ \\
\hline & With simple sole & Middle of the slope & Wide visibility & (?), not very impressive \\
\hline & With simple sole & Slope & - & $\begin{array}{l}\text { High in relation to the ground, } \\
\text { impressive }\end{array}$ \\
\hline & With simple sole & Middle of the slope & Wide visibility & $\begin{array}{l}\text { High in relation to the ground, } \\
\text { impressive }\end{array}$ \\
\hline & With simple sole & Middle of the slope & Wide visibility & $\begin{array}{l}\text { High in relation to the ground, } \\
\text { impressive }\end{array}$ \\
\hline & With simple sole & Middle of the slope & Wide visibility & (?), impressive \\
\hline & With simple sole & Middle of the slope & Wide visibility & - \\
\hline & With simple sole & Top of the hill & Wide visibility & $\begin{array}{l}\text { Little detached from the ground, } \\
\text { not very impressive }\end{array}$ \\
\hline & With sole and heel & Middle of the slope & Wide visibility & High in relation to the ground \\
\hline & With sole and heel & Bottom of the slope & Wide visibility & High in relation to the ground \\
\hline & With sole and heel & Bottom of the slope & Wide visibility & Little detached from the ground \\
\hline \multirow{3}{*}{$\begin{array}{c}1 \text { pair } \\
2 \text { individual }\end{array}$} & $\begin{array}{l}\text { With simple sole } \\
\text { With simple sole }\end{array}$ & $\begin{array}{l}\text { Bottom of the slope } \\
\text { Bottom of the slope }\end{array}$ & Wide visibility & $\begin{array}{l}\text { Little detached from the ground } \\
\text { (?) }\end{array}$ \\
\hline & With simple sole & Top of the plateau & Wide visibility & $\begin{array}{l}\text { Little detached from the ground, } \\
\text { not very impressive }\end{array}$ \\
\hline & With sole and heel & Bottom of the slope & Wide visibility & Little detached from the ground \\
\hline \multirow{2}{*}{ More than 10} & 24 simple soles & Valley bottom & Wide visibility & $\begin{array}{c}\text { High in relation to the ground, } \\
\text { impressive }\end{array}$ \\
\hline & 37 sole and heels & High on the slope & Wide visibility & $\begin{array}{l}\text { Little detached from the ground, } \\
\text { not very impressive }\end{array}$ \\
\hline
\end{tabular}

The identification of the age of the recorded individuals, from the dimensions of the shoeprints, was based on several studies of physical anthropology and historical sources [16-22]. Adult individuals were considered to be persons aged over 14 or 15, i.e., they were associated to shoeprints measuring over $23 \mathrm{~cm}$ in length [19-21] ${ }^{9}$. Thus, considering the results of Table 3, most shoeprints recorded with simple soles seem to correspond to juvenile or young individuals ( $70 \%$ ), with adults being only $25 \%$ of the sample. In this perspective, its recording may be articulated with the materialisation of rites of passage from youth to adulthood, involving travel or pilgrimages to certain places and at certain times of the year, possibly accompanied by adults—as the officiants of the ceremonies.

As for shoeprints with sole and heel depictions, which indicate a more elaborate form of footwear, the number of adults is higher than that of young people, representing $51 \%$ and $39 \%$ of the sample, respectively. Given these data, the hypothesis put forward for the shoeprints of the previous typology does not seem to fit, unless these shoeprints materialise "more elaborate shoes" that, for this reason, would have dimensions slightly increased compared to the real foot size of the people who used them. One possibility is that these shoeprints belong to members of social groups in which certain rites of

9 It was at this age that young Athenian women usually married for the first time; for the Roman period a table of the division of ages is known, provided by Isidoro de Sevilla, in the seven century, which refers to the existence of infantia (0-7 years), puertia (8-14 years), adulescentia (15-28 years), and iuuentus (29-50 years), wherein adulescentia is considered to be the start of adulthood, since pueritia comprises a preparatory stage for public life; in the later Roman period, it is known that the age from which men wore a toga was lowered, existing cases in which this would have happened between the ages of 14 and 16 [19]; in a study on child and adolescent development/transitions into adulthood, focused on Canadian indigenous populations, Simard and Blight [20] state that adulthood (Nitawigiwin) occurred between the ages of 15 and 50; a study on the ages of the prehistoric populations of the middle and lower Yellow River Valley in China, also considers adults to be all those above 15 years of age [21]. 
passage into adulthood would have taken place at an older age; another is that they belonged to a restricted social group, different from persons associated to shoeprints with simple soles, and who could, in some cases, officiate the rites performed by those who walked barefoot. A third hypothesis can also be put forward: that the rites of passage themselves implied a change of social status which, for some of the members, would imply the possibility of going from barefoot to wearing shoes.

In this category, there are still four shoeprints, i.e., $10 \%$ of the sample, whose extraordinary dimensions (greater than or equal to $40 \mathrm{~cm}$ ), seem to indicate the importance, real or mythical, of the persons who recorded them or a reference to imaginary beings or persons who would participate in these ceremonies.

As for the orientations, the shoeprints of both types are oriented essentially to the northwest (60\% in cases with simple soles and $76 \%$ in other cases), which correspond to sunset at the summer solstice. Some of these engravings are also directed to the southeast ( $10 \%$ in both cases), i.e., to sunrise at the winter solstice, and west ( $8 \%$ and $7 \%$ ), which corresponds to sunset at the spring and autumn equinoxes. Some shoeprints are also oriented towards the southwest ( $3 \%$ and $2 \%$ ), which corresponds to sunset at the winter solstice. To the northeast, i.e., to sunrise at the summer solstice, there have been only cases associated with characters with shoeprints provided with soles and heels. To the north and south, there are only a few cases associated with shoeprints with simple soles. Analysis of this data provides evidence for the hypothesis that the ceremonies performed in these places, although they may be related to trips associated with rites of passage or pilgrimages to places of great symbolic significance, took place preferably during the summer solstice, although, also at other important times in the solar cycle. This relates the possible rites of passage with the importance of the solar calendar and possibly to solar cults. It should also be noted that the sunset seems to have greater significance than the sunrise in the ceremonies underlying these recorded motifs.

It is concluded that, in the popular imagery of Northwest Portugal, outcrops with footprints and shoeprints are often associated with place-names and legends of Christian origin, almost always related to the journey or the pilgrimage of a saint prior to reaching a sacred place, which may reflect remnants of its original interpretation [12]. This also demonstrates the great heritage potential of these places that "obstinately" persist in the memories of rural populations.

Author Contributions: Conceptualisation, J.M. and A.M.S.B.; Formal analysis, J.M. and A.M.S.B.; Research, J.M.; Methodology, J.M.; Supervision, A.M.S.B.; Validation, A.M.S.B.; Visualisation, J.M. and A.M.S.B.; Writing-original draft, J.M.; Writing-review and editing, J.M. and A.M.S.B.

Funding: This work was carried out in the scope of the Rota de Arte Rupestre do Noroeste: Um projeto de Turismo Cultural/Northwest Rock Art Route: A Cultural Tourism Project (RAR Project-October 2014), and financed under the scope of Lab2PT, and the Research Grant funded by the FCT-UMINHO/BI/317/2018—Lab2pt/University of Minho, Braga, Portugal.

Conflicts of Interest: The authors declare no conflict of interest.

\section{References}

1. Gomes, M.V.; Monteiro, J.P. As rochas decoradas da Alagoa, Tondela-Viseu. O Arqueologo Português 1977, $3^{a}$ Série, VII-IX, 145-164.

2. Benito, L.; Grande, R. Nuevos Santuarios Rupestres prehistóricos en las provincias de Zamora y Salamanca. Zephyrus 1994, 47, 113-131.

3. Sevillano, M.C.; Bécares, J. Grabados rupestres en la Huerta (Caminomorisco, Cáceres). Zephyrus 1998, 51, 289-302.

4. Santos, M.; García, M.V. Petroglifos podomorfos del Noroeste Peninsular: Nuevas comparaciones e interpretaciones. Revista de Ciências Históricas 2000, 15, 7-40.

5. García, M.V.; Santos, M. Petroglifos podomorfos de Galicia e investiduras reales célticas: Estudio comparativo. Archivo Español de Arqueologia 2000, 73, 5-26. [CrossRef]

6. García, M.V. Imágenes, textos, paisajes e ideas: Los santuarios castreños en contexto. In Profano y Pagano en el Arte Gallego; Castiñeiras, M.A., Díez, F., Eds.; Servicio de Publicacións da USC: Santiago de Compostela, Spain, 2003; pp. 37-149. 
7. Llinares, M. Interpretación y sobreinterpretación en la reconstrucción histórica: Una reflexión sobre los petroglifos con podomorfos en Galicia. Zephyrus 2009, 64, 39-51.

8. Gomes, M.V. Arte Rupestre do Vale do Tejo. Um Ciclo Artístico-Cultural Pré e Proto-Histórico. Ph.D. Thesis, FCHS-UN, Lisbon, Portugal, 2010. (Unpublished).

9. Ribeiro, N.; Joaquinito, A.; Pereira, S. O podomorfismo na arte rupestre da fachada atlântica, que significado? In Proceedings of the Resumos do V Encontro de Arqueologia do Sudoeste Peninsular, Almodôvar, Portugal, 18-20 November 2010; pp. 201-211.

10. Abreu, M.E. Rock-Art in Portugal. History, Methodology and Traditions. Ph.D. Thesis, Universidade de Trás-os-Montes e Alto Douro, Vila Real, Portugal, 2012. (Unpublished).

11. Garcês, S. Cervídeos: Símbolos e Sociedade nos Primórdios da Agricultura no Vale do Tejo. Ph.D. Thesis, University of Trás-os-Montes and Alto Douro, Vila Real, Portugal, 2016.

12. Moreira, J. Podomorfos na Fachada Ocidental do Noroeste de Portugal, Entre os Rios Douro e Minho. Master's Thesis, University of Minho, Braga, Portugal, 2018.

13. Carrasco, J.; Pachón, J.A.; Gámiz, J. Los separadores de hileras de collar en la Prehistoria Peninsular. Un estudio crítico. Antiquitas 2009, 18, 5-69.

14. Paço, A. Sandálias de Alapraia. In Corona de Estudios que a Sociedad Española de Antropologia, Etnografia y Prehistoria dedica a sus Mártires; Sociedad Española de Antropologia, Etnografia y Prehistoria: Madrid, Spain, 1941; pp. 213-219.

15. Coelho, L. Nueva estela insculturada proveniente del Baixo Alentejo (Ervidel, Portugal). Trabajos de Prehistoria 1975, 32, 195-198.

16. Davenport, C.B. The growth of the human foot. Am. J. Phys. Anthropol. 1932, 17, 167-211. [CrossRef]

17. Meredith, H.V. Human foot length from embryo to adult. Hum. Biol. 1944, 16, 207-282.

18. Anderson, M.; Blais, M.; Green, W.T. Growth of the normal foot during childhood and adolescence: Length of the foot and interrelations of foot, stature, and lower extremity as seen in serial records of children between 1-18 years of age. Am. J. Phys. Anthropol. 1956, 14, 287-308. [CrossRef] [PubMed]

19. Ferreira, L.N.; Rodrigues, N.S. Tornar-se adulto na Antiguidade Clássica-Tornar-se adulto na Grécia antiga: Normas, práticas e representações. In Jovens Adultos; Fonseca, A.C., Ed.; Almedina: Coimbra, Portugal, 2014; pp. 87-130.

20. Simard, E.; Blight, S. Developing a culturally restorative approach to Aboriginal child and youth development: Transitions to adulthood. First Peoples Child Fam. Rev. 2011, 6, 28-55.

21. Wang, J. Research on the prehistoric population age structure in the Middle and Lower reaches of the Yellow River valley. Chin. Archaeol. 2008, 8, 163-167.

22. Cruz, C.; Cunha, E. Os vestígios osteológicos humanos do Paleolitico Português: Revisão bibliográfica e análise dos dados. Antropol. Port. 2008, 24, 75-93. [CrossRef]

23. Bettencourt, A.M.S. Gravuras Rupestres do Noroeste Português para além das Artes Atlântica e Esquemática. In Arqueologia de Portugal. Estado da Questão; AAP: Lisbon, Portugal, 2017; pp. 1053-1067.

24. Bettencourt, A.M.S. Post-Palaeolithic rock art of north-western Portugal: An approach. In Recorded Places, Experienced Places. The Holocene Rock Art of the Iberian Atlantic Northwest; Bettencourt, A.M.S., Santos, M., Sampaio, H.A., Cardoso, D., Eds.; British Archaeological Publishing: Oxford, UK, 2017; pp. 123-150.

25. Alves, L.B. The Movement of Signs. Post Glacial Rock Art in North-Western Iberia. Ph.D. Thesis, University of Reading, Reading, UK, 2003. (Unpublished).

26. Alves, L.B.; Reis, M. Memoriais de pedra, símbolos de identidade. Duas novas peças escultóricas de Cervos (Montalegre, Vila Real). In Estelas e Estátuas-Menires: Da Préà Proto-História. Actas das IV Jornadas Raianas (Sabugal, 2009); Vilaça, R., Ed.; Municipal Council: Sabugal, Portugal, 2011; pp. 187-216.

27. Alves, L.B.; Reis, M. Tattooed landscapes. A reassessment of Atlantic Art distribution, research methods and chronology in the light of the discovery of a major rock art assemblage at Monte Faro (Valença, Portugal). Zephyrus 2017, 80, 49-67.

28. Bettencourt, A.M.S. A Pré-História do Noroeste Português/The Prehistory of the North-Western Portugal; ARKEOS: Braga, Portugal; CITCEM: Tomar, Portugal, 2013.

29. Bradley, R.; Sheridan, A. Croft Moraig and the chronology of stone circles. Proc. Prehist. Soc. 2005, 71, 269-281. [CrossRef]

30. Sanches, M.J. A Pré-História Recente de Trás-os-Montes e Alto Douro; SPAE: Porto, Portugal, 1997. 
31. Sanches, M.J. Abrigos com pinturas rupestres esquemáticas da Serra de Passos $/ \mathrm{St}^{\mathrm{a}} \mathrm{Comba}$. In História do Douro e do Vinho do Porto. História Antiga da Região Duriense; Almeida, C.A.B., Ed.; Afrontamento: Porto, Portugal, 2006; Volume 1, pp. 126-129.

32. Santos-estévez, M. Petroglifos y Paisage Social en la Prehistoria Reciente del Noroeste de la Península Ibérica; TAPA: Santiago de Compostela, Spain, 2007.

33. Santos, M. Da "Arte Atlantica" no contexto europeu: Conceitos, problematicas e perspectivas-unha vision diacronica da Arte Atlantica dentro dun novo marco cronoloxico. In Artes Rupestres da Pré-História e da Proto-História: Paradigmas e Metodologias de Registo; DGPC: Lisboa, Portugal, 2013; pp. 226-235.

34. Ribeiro, F.N. O Bronze Meridional Português; Junta Distrital de Beja: Beja, Portugal, 1965.

35. Paço, A.; Nunes Ribeiro, F.; Franco, G.L. Inscriçao ibérica da Corte do Freixo (Almodóvar). Zephyrus 1965, 16, 99-107.

36. Almagro, M. Las Estelas Decoradas del Suroeste Peninsular; Consejo Superior de Investigaciones Científicas: Madrid, Spain, 1966.

37. Jiménez, F. Sidereum Ana I. el río Guadiana en Época Post-Orientalizante; CSIC: Mérida, Mexico, 2008.

(C) 2018 by the authors. Licensee MDPI, Basel, Switzerland. This article is an open access article distributed under the terms and conditions of the Creative Commons Attribution (CC BY) license (http:/ / creativecommons.org/licenses/by/4.0/). 